\title{
RELATIVE CLAUSE TRANSFER STRATEGY AND IMPLICATION ON CONTRASTIVE ANALYSIS HYPOTHESIS
}

\author{
Sudarsono \\ Lecturer, FKIP, Tanjungpura University, Indonesia \\ Corresponding Author Email: sudarsono@ fkip.untan.ac.id
}

\begin{tabular}{|c|c|}
\hline Article Info & Abstract \\
\hline Article History & \multirow{10}{*}{$\begin{array}{l}\text { Foreign language learners may transfer their previous language properties into } \\
\text { that of the target language either positively or negatively. The present study was } \\
\text { designed to investigate the transfer strategy from the Indonesian relative clauses } \\
\text { to the English ones. It was a descriptive study. The data were collected from the } \\
\text { theses submitted by the Master's Program students of English Language } \\
\text { Education to the university. The study found out that most students relativized } \\
\text { subjects successfully but frequently failed to relativize the object of which } \\
\text { Indonesian could not do it. The students were not found relativizing indirect } \\
\text { objects, oblique, and comparison of which Indonesian did not permit. In } \\
\text { conclusion, the study supported the strong contrastive analysis hypothesis. }\end{array}$} \\
\hline ptember 2021 & \\
\hline $\operatorname{Rev}$ & \\
\hline Published: $O$ & \\
\hline Key & \\
\hline Interlingual Transfer; & \\
\hline Contrastive Analysis; & \\
\hline Error Analysis; & \\
\hline Relativi & \\
\hline & \\
\hline
\end{tabular}

How to cite: Sudarsono. (2021). Relative Clause Transfer Strategy and Implication on Contrastive Analysis Hypothesis, JOLLT Journal of Languages and Language Teaching, 9(4) pp. 452-461. https://doi.org/10.33394/jollt.v\%vi\%i.4055

\section{INTRODUCTION}

Indonesian is generally learned and used by its speakers as a second language. Most speakers master Indonesian after their mother tongues such as Javanese, Sundanese, Malay, and Iban. However, Indonesian is now becoming a rapidly-developing mother tongue of the younger urban generation. English is taught at school in Indonesia as a first foreign language. It is learned in the classroom setting; it is not used to interact with the surrounding people. For schooling purposes, the students take Indonesian and English as compulsory courses (Silalahi, 2016). The former is taught as the national language and the latter as the first foreign language. In learning English, Indonesian speakers face ease in some points, but constraints in others. One of the arguments is that there are similarities and differences between these two languages (Sudarsono, 2018). The similarities and differences lie in grammar, pronunciation, lexemes, and other aspects of language.

Numbers of studies have been done on negative transfer mostly from the students' L1 to English. They included the studies on the interference from Indonesian to English (Sudarsono, 2011 \& 2018; Said, 2012), from Turkish to English (Erkaya, 2012; Erarslan \& Hol, 2014; Uzun, 2020), Arabic into English (Sabbah, 2015; Dweik \& Othman, 2017), from Thai to English (Watcharapunyawong \& Usaha, 2013), from Chinese to English (Ma \& Tan, 2013; Zhao, 2019), and from Lithuanian to English (Daukšaite, 2019). Other researchers studied the interference from Malay to Mandarin (Ling, 2020), and from Spanish to Basque (Erdocia \& Laka, 2018).

Indonesian students may succeed in learning English where both languages share properties. For example, they translate Indonesian (1) into English (2) easily. Both languages apply the same grammatical system, namely, SVO where S refers to subject, V to verb, and O to object. As long as Indonesian speakers master English vocabulary, they will be able to translate (1) to (2) successfully. 


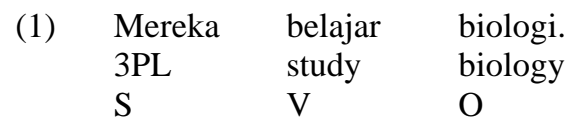

(2) They study biology.

Unfortunately, Indonesian speakers may experience difficulties if the act of 'study' (3) occurred in the past. English applies the rule that the past activities or circumstances and the verbs (predicate nuclei) are marked by a past tense morpheme. Therefore, 'belajar' shown in (3) is translated into (4) by inflecting the verb 'study' into 'studied' (4). If the verb "study" is not inflected into the past tense form as shown in (5), this sentence will not be acceptable to the native speakers of English.

(3) Mereka belajar biologi kemarin.

(4) They studied biology yesterday.

(5) *They study biology yesterday.

Canonically, the English predicators are verbal, whereas the Indonesian ones can be either verbal or non-verbal (Liusti, 2016). At this point, the students may transfer the Indonesian nonverbal predicate (6) into the English negatively as illustrated in (7). The predicate "very fat" (7) is an adjective phrase, not a verb phrase. This adjective phrase must be headed by an auxiliary to function as the predicate of (8).

(6) Aminah sangat gemuk.

(7) *Aminah very fat.

(8) Aminah is very fat.

As shown in the above examples, language students may transfer the properties of their previous language into the target language positively or negatively (Phoocharoensil \& Simargool, 2010). The former occurs when one uses his previous language in the target language without causing interlingual errors. The latter occurs when the previous language properties are applied to the target language and the result is unacceptable in the target language.

Since Indonesian and English are similar in some linguistic aspects and different in others, the study in this field is very broad. Because of the limited time and funds, the present research covered only the relative clause transfer of Indonesia into that of English. This study was also aimed to investigate whether the transfer made by the students implied the Contrastive Analysis Hypothesis. The present research was designed to answer the questions "What strategy did the Indonesian-speaking students of the English Language Study Program write English relative clauses in English?" and "Did the results of this study support strongly or weakly against the Contrastive Analysis Hypothesis?" The purposes of this study were to examine how often the students transferred the Indonesian relative clause system into the English one and to confirm whether the negative transfer could be used as a prediction of the difficulty for Indonesian students to master English.

A relative clause refers to an expansion clause that involves a relative pronoun. The relative pronouns is 'yang' in Indonesian and 'sing' in Javanese as reported by Ambarita \& Mulyadi (2019) who studied "Relative Clause of Indonesian and Java Language" and Ekaristianto et al. (2020) who did research entitled "Construction of Relative Clause in the Indonesian Language". Shibatani (2008) reported that Sasak and Sumbawa, eastern Indonesia languages apply a relative pronoun 'saq' equivalent with 'yang' in Indonesian and 'sing' in Javanese to have a relative clause.

The relative pronouns 'yang', 'sing', and 'saq' here according to the primary concept of a relative clause, "describe a noun phrase in which its relative pronouns refer back to the noun phrase upstream" (Ambarita \& Mulyadi, 2019; Sari et al., 2017). The examples of relative 
clauses in Indonesian and Javanese are illustrated in (9) and (11) respectively. The relative clauses are written italic and the relative pronouns are written bold. The clauses in (10) and (12) are their respective equivalence in English. The example of relative clauses in Sasak (Shibatani, 2008) is written italic as shown in (13), equivalent with (14) in English.

(9) Kakak saya yang tinggal di Banjarnegara_mengajar di sekolah dasar.

(10) My sister who lives in Banjarnegara teaches in an elementary school.

(11) Ayam sing nembe mabur_ndeke inyong.

(12) The chicken which just flew belongs to me.

(13) $\mathrm{Mu}=\mathrm{k}$ gitaq acong [saq kakoq=em wiq $]=$ no

PAST $=1$ see dog REL bite=2 yesterday=that

(14) I saw the dog that bit you yesterday.'

Unlike Indonesian, Javanese and Sasak, English distinguishes relative pronouns for human subjects 'who' (10) and non-humans 'which' (12) and the relative pronouns that can be used for both namely, 'that', which can be seen in (15) and (16).

(15) My brother is the man that is sitting next to the dean.

(16) The pencil that my younger brother borrowed last night was lost.

In addition to the subjects (Subj), English can relativize direct objects (DO), indirect objects (IO), obliques (Obl), genetives (Gen), and comparative objects (OComp) (Fox, 1987; $\mathrm{Xu}, 2011)$. The examples of English relative clauses are underlined and the relative pronouns are written bold from (17) to (21) respectively.

(17) I saw the man who(m) the police arrested.

(18) I saw the man to whom you gave a lift.

(19) I saw the knife with which you cut the meat.

(20) I saw the man whose car rolled over the cliff.

(21) I saw the man than whom no one is taller.

Keenan and Comrie reported their research finding that some relativizations were more accessible than others (Comrie \& Keenan, 1979; Shibatani, 2008; Hanafi et al., 2020). The hierarchical formula is as follows:

(22) Subj > DO > IO > Obl > Gen > OComp

where ' $>$ ' in the above formula means 'more accessible than'. Formula (22) shows that Subj is more accessible to a relativity than DO; DO is more accessible than IO; IO is more accessible than $\mathrm{Obl}$; Obl is more accessible than Gen; and Gen is more accessible than OComp. As shown in the examples of (17) - (21), English can relativize them. On the other hand, Indonesian can only relativize them partially.

From the above explanation, the relativization in English cannot be fully done with the same strategy in Indonesian. For example, (17) cannot be relativized by the same strategy in Indonesian. This language will change the clauses first from the active voice to the passive one, so the object of the active transitive verb can be promoted to be the subject of the passive as shown in (23). Example (24) is not accepted by the Indonesian native speakers because it is the object that has been relativized.

(23) Saya melihat orang yang ditangkap polisi.

(24) *Saya melihat orang yang polisi menangkap.

Referring to the above discussion, there is a difference between the relative forms of Indonesian and that of English. According to the theory of contrastive analysis, the difference between the two languages may make students have difficulty at the point of difference between the two languages (Phoocharoensil \& Simargool, 2010). There are two versions of Contrastive Analysis Hypotheses, namely, the strong version (the prior version) and the weak version (the posterior version) (Tajareh, 2015). 
According to the strong version of the hypothesis, a teacher can predict the difficulties that students may encounter when they learn the target language (Fauziati, 2014). The claim is based on the constraint that the students faced lies in the grammatical forms that are not applied in the target language, but they are used in the students' mother tongue. The grammatical form of the mother tongue transferred into the target language is called negative transfer.

The grammatical transfer of the mother tongue like this will produce the wrong form in the target language (Sudarsono, 2018). However, such a prediction is not supported with sufficient data. It should also not be difficult for the students to make the grammatical forms at the syntactic forms (positive transfer) that both languages share. According to the weak version, the students' difficulties are not entirely due to differences in the two languages.

\section{RESEARCH METHOD}

The present study was a contrastive analysis. The procedure included describing Indonesian and English relative clauses explicitly, selecting the forms, the regulations, or the structure of Indonesian and English relative clauses to contrast, contrasting the relative clause system with that of English and establishing the Indonesian clause system relationship with that of English, and making predictions based on the analysis conducted. The data were sorted out from the theses submitted by the graduates from the Master's Program of English Language Education, Teacher Training and Education Faculty, Tanjungpura University from 2016 to 2020. They were English teachers from state and private schools/universities from various regions within West Kalimantan, Indonesia. The theses were selected randomly to get the real picture of the students' strategy in expressing their thoughts as native speakers of Indonesian in English. The selected theses were treated as corpora from which the research data were obtained.

The data sorted out from these corpora were the English relative clauses that were written in Indonesian grammar such as "which will be used by the researcher" shown in (25) or in English such as "which the researcher will use" as illustrated in (26). The relative clause of (25) is grammatical, but not common in English. The data excluded the ungrammatical forms outside the relative clause system such as the ungrammatical finite predicator that disagreed with the noun that was the antecedent of the subject or the object as illustrated in (27). In this example, the finite predicator "is" is incompatible with the subject whose antecedent is in the plural form, "teachers".

(25) The approach which will be used by the researcher is ...

(26) The approach which the researcher will use is ...

(27) ... certified teachers that is teaching twenty-four periods in a week ...

All relative clauses were collected and classified according to what has been relativized and the frequency of each classification was computed. The conclusion from this analysis was intended to provide an answer whether in expressing relative clauses in English using the rules of Indonesian relative clauses, English relative clauses, or distinctive forms that are neither Indonesian nor English. Besides, the findings of the present study were intended to answer whether they support the strong or the weak version of the contrastive analysis hypotheses.

To determine whether the findings were supportive to the strong or to the weak version of Contrastive Analysis Hypotheses, the frequency of the negative transfer from Indonesian relative clauses into English relative clauses were classified into 5 categories, namely, Very Weak, Weak, Moderate, Strong, and Very Strong as shown in the table below. 
Table 1

Percentage of the occurrence and the classification of negative transfer

\begin{tabular}{ccc} 
No. & $\begin{array}{c}\text { Percentage of Transfer Negative } \\
\text { Frequency }\end{array}$ & Category \\
\hline 1 & $0-20 \%$ & very weak \\
\hline 2 & $21-40 \%$ & weak \\
\hline 3 & $41-60 \%$ & moderate \\
\hline 4 & $61-80 \%$ & strong \\
\hline 5 & $81-100 \%$ & very strong \\
\hline
\end{tabular}

\section{RESEARCH FINDINGS AND DISCUSSION}

The data analysis showed that the students applied various strategies in constructing English relative clauses. The strategies encountered in the corpora involved relativizing Subj covering the Subj of active and passive clauses, relativizing DO, and relativizing Obl. The example of relativizing Subj encountered in the corpora is (28). In this example, the construction of "who suffer from communication apprehension" is a relative clause. The word 'who' in this clause is a relative pronoun that functions as the subject of the clause and refers to its antecedent, "people".

(28) People [who suffer from communication apprehension] are ...

The second type of relative clause written in the corpora was a relative clause whose clause was constructed in a passive clause of which the subject was resulted by promoting the DO of an active clause. An example of this clause type is 'which was played by the teacher' as illustrated in (29). The relative pronoun 'which' of this clause is the subject of a passive clause (29).

(29) The music [which was played by the teacher] could ...

Another type of relative clause that the students expressed in their theses was the relative clause whose object was immediately relativized. The word 'that' of 'that a writer uses to communicate' (30) is a relative pronoun functioning as DO in this clause.

... the expression [that a writer uses to communicate ...]

The fourth type of relative clause was the relative clause that relativized an oblique (Obj of a preposition). In (31), the word "which" is the oblique of the preposition 'through' which is relativized in this clause.

... small groups [through which students work together...]

The research findings also showed that the most frequently encountered strategy was that relativizing Subj. This strategy was then followed by the clauses that relativized obliques and direct objects. The following graph shows the frequency of occurrence of relative clauses encountered in this study.

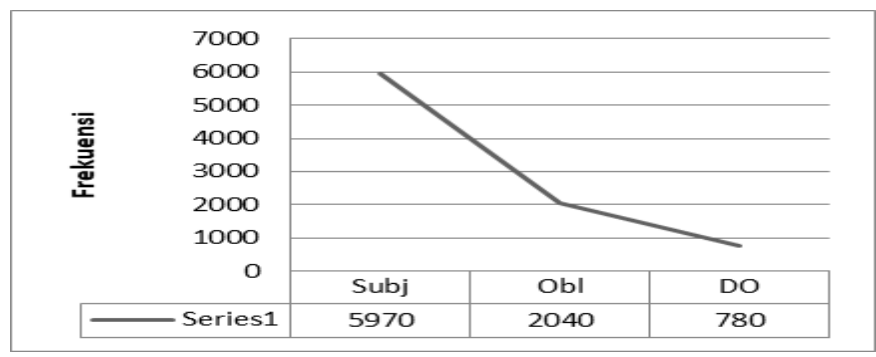

Graph 1: Frequency of each type of relative clause 
Then, the students relativized the subjects in two strategies. The first strategy was relativizing the subjects of active transitive verbs, and the second one was through promoting the direct objects of active transitive verbs as the subjects of their passive counterparts. The first strategy could be done by both Indonesian and English speakers without any potential errors because they shared properties. Erarslan and Hol (2014) and Dweik and Othman (2017) argue for the facilitation of previous language knowledge to the new learning of the target language for the application of similar rules.

Unfortunately, the Indonesian speakers more frequently demonstrated the second strategy. Indonesian system does not permit to relativize the direct objects of active transitive verbs. Ambarita \& Mulyadi (2019) and Sudarsono (2011) urge that to relativize Indonesian DO well, the speakers must paraphrase the active clause first into its passive counterpart to promote the DO of the active clause as the Subj of a passive sentence. This mechanism is acceptable grammatically, but not common in practice among the English native speakers.

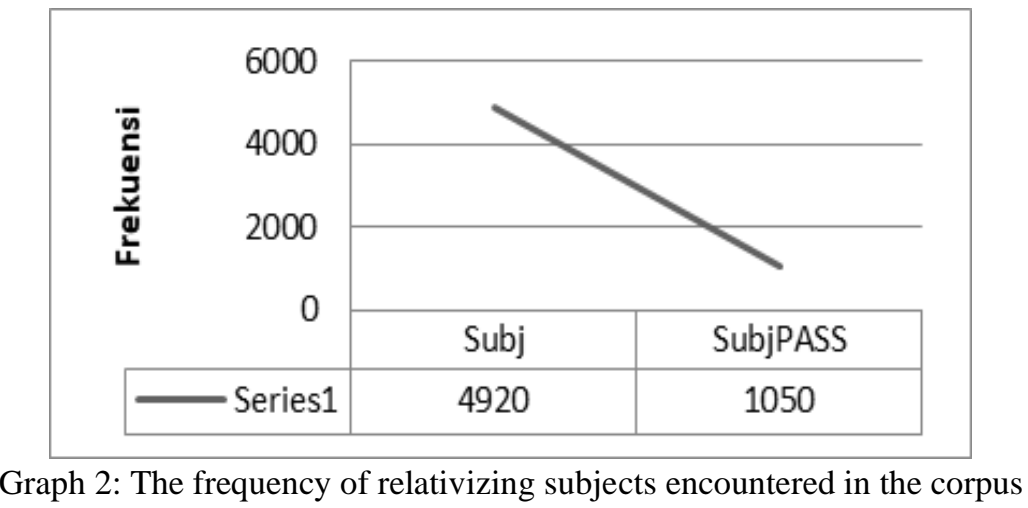

Instead of relativizing the direct objects as commonly applied in English, the students more often relativized the direct objects in active clauses by promoting the direct objects as the subjects of passive clauses as shown in the graph below.

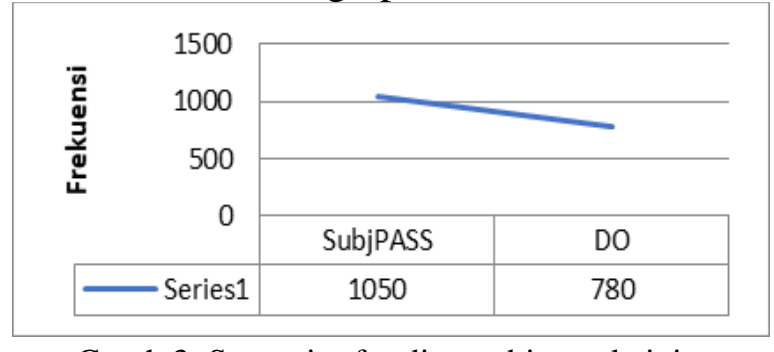

Graph 3: Strategies for direct object relativity

As can be seen in the above graph, the students more often relativized the direct objects with the relativizing strategy applied in Indonesian, that is, promoting the direct objects as the subjects of passive clauses rather than using the typical strategy applied in English, that is, relativizing the direct objects while still maintaining the clauses in active clauses. Alvin (2014) suggests that the relative clauses be expressed in the passive voice when they are intended to "draw attention to the affected phenomenon rather than the agent". The examples of the relative clauses in the passive voice where the promoted DO as the Subj in passive voice are 'which are usually interpreted' and 'which is increasingly debated' as shown respectively in the following underlined examples.

(32) These experiments however usually measure longer distances by small rate increases which are usually interpreted_in a semiquantitative way yielding relative distance information. 
... which is increasingly debated as a trigger for forest decline . . .

The last finding of the present research was that the negative transfer of Indonesian into English on the relativizing strategy of 1050 direct objects fell in $41-60 \%$. This range is classified as moderate, i.e. under 'strong' and above 'weak'. However, when viewed from the closeness of the range limits, the finding is closer to 'strong' than to 'weak'. Therefore, the prediction of a negative transfer is closer to the prediction of a stronger version.

This finding is higher than the finding reported by Erarslan \& Hol (2014) who investigating the interference of Turkish into English that covered the interference in vocabulary, prepositions, and tenses as shown in the following table.

Table 2

The interference of Turkish into English

\begin{tabular}{lccc}
\multicolumn{1}{c}{ Level } & $\begin{array}{c}\text { Lexemes } \\
\text { \% }\end{array}$ & $\begin{array}{c}\text { Prepositions } \\
\mathbf{\%}\end{array}$ & $\begin{array}{c}\text { Tenses } \\
\mathbf{\%}\end{array}$ \\
\hline Elementary & 35 & 41 & 19 \\
\hline Pre-Intermediate & 21.90 & 21.49 & 19.8 \\
\hline Intermediate & 28.33 & 21.33 & 21.23 \\
\hline
\end{tabular}

\section{CONCLUSION}

Indonesian and English are two languages that come from different language families. Even so, these two languages have similarities and differences in their relevant aspects. The students who speak Indonesian as their mother tongue or as their national language are predicted to experience convenience when learning phrases or sentences applying the same grammatical system with English, for example, they are predicted to have difficulty when learning phrases or sentences that Indonesian and English do not share.

The present study examined the Indonesian negative transfer or interference on English in relative clauses encountered in the theses that the English students of the Master's Program submitted to the university. The research found out that the students only expressed some of the relative clauses that were possible in the language, that is, relativizing Subj, DO, and Obl. The students relativizing the subjects were very high in number compared to those who relativized DO, and Obl. In relativizing DO, the students applied two strategies, namely, the DO relativizing strategy in Indonesian and also the DO relativizing strategy in English. The DO was relativized by students via the Indonesian mechanism to relativize the DO in English. The students' negative transfer in relative clauses was considered 'moderate', closer to the prediction of the "strong" version than with the prediction of the "weak" version.

The transfer of the Indonesian relative clauses into English encountered in the theses submitted by the graduates of English Language Education, Teacher Training and Education Faculty, Tanjungpura University is categorized into a fossilized form, not developmental form. Jalali and Shojaei (2012) claim that the fossilized errors are expressed by the senior (advanced) students or even English teachers, and the developmental errors are encountered among ELT beginner and less proficient students. Finally, the present research also reported that the previous language transfer into the target language supports the strong version of the Contrastive Analysis Hypothesis. It is at the level of almost "strong".

Referring to the above research findings, it is necessary to give suggestions to both students and practitioners in TEFL including teachers and lecturers whose previous language is Indonesian. They need to understand contrastive analysis when learning or teaching English as a foreign language. They need to know the grammatical properties, for instance, that Indonesian and English share and do not share. They do not need to worry about difficulties when learning or teaching an additional language at the properties where the previous and the target languages share. The similarities of both languages are facilitative. However, they need to pay more 
attention to the properties that these two languages do not share. At this point of difference, the students are predicted to have constraints even though, not very 'strong'. They mostly prefer to use the system of the previous language and to avoid the system of the new language.

\section{ACKNOWLEDGEMENT}

I would like to express my sincere gratitude to Dr. Martono, the Dean of Teacher Training and Education Faculty, Tanjungpura University, who approved the funding for the research through 'PNBP DIPA FKIP Untan 2019'. I also thank the Chair of Languages and Arts Education Department, and the Chair of Master's Program as well as the lecturers, students, graduates, and staff for the support and the contribution to the research.

\section{REFERENCES}

Alvin, L. P. (2014). The passive voice in scientific writing. The current norm in science journals. Journal of Science Communication, 13(1), 1-16. https://jcom.sissa.it/archive/13/01/JCOM_1301_2014_A03/JCOM_1301_2014_A03.pdf ?utm_source=hootsuite\&utm_campaign=hootsuite

Ambarita, R., \& Mulyadi. (2019). Relative Clause of Indonesian and Java Language. Scholars International Journal of Linguistics and Literature, July, 85-89. https://doi.org/10.21276/sijll.2019.2.5.1

Comrie, B., \& Keenan, E. L. (1979). Noun Phrase Accessibility Revisited. Language, 55(3), 649-664. https://doi.org/10.2307/413321

Daukšaitè, A. (2019). Negative Transfer in Lithuanian Students' Writing in English. Sustainable Multilingualism, 14(1), 107-122. https://doi.org/10.2478/sm-2019-0005

Dweik, B. S., \& Othman, Z. A. (2017). Lexical and Grammatical Interference in the Translation of Written Texts from Arabic Into English. Academic Research International, 8(3), 6570 .

https://www.researchgate.net/publication/320004399_LEXICAL_AND_GRAMMATIC AL_INTERFERENCE_IN_THE_TRANSLATION_OF_WRITTEN_TEXTS_FROM_ ARABIC_INTO_ENGLISH

Ekaristianto, F. B. H., Purnanto, D., \& Sumarlam. (2020). Construction of Relative Clause in Indonesian Language. International Journal of Multicultural and Multireligious Understanding, $\quad 7(1), \quad 410-420$. https://doi.org/http://dx.doi.org/10.18415/ijmmu.v7i1.1295

Erarslan, A., \& Hol, D. (2014). Language interference on English: Transfer on the vocabulary, tense and preposition use of freshmen Turkish EFL learners. ELTA Journal, 2(2), 4-22. http://eltajournal.org.rs/wp-content/uploads/2014/12/IV-Language-interference-onEnglish-transfer-on-the-vocabulary-tense-and-preposition-use-of-freshmen-TurkishEFL-learners-by-Ali-Erarslan-and-Devrim-Hol.pdf

Erdocia, K., \& Laka, I. (2018). Negative transfer effects on L2 word order processing. Frontiers in Psychology, 9(MAR), 1-10. https://doi.org/10.3389/fpsyg.2018.00337

Erkaya, O. R. (2012). Vocabulary and L1 Interference - Error Analysis of Turkish Students ' English Essays. MEXTESOL Journal, 36(2), 1-11. http://www.mextesol.net/journal/index.php?page=journal\&id_article=167

Fauziati, E. (2014). Contrastive Analysis, Transfer Analysis, Error Analysis, and Interlanguage: Four Concepts One Goal. Ahmad Dahlan Journal of English Studies, 1(1-2), 8-18. https://doi.org/10.26555/adjes.v1i1-2.1680

Fox, B. A. (1987). The Noun Phrase Accessibility Hierarchy Reinterpreted: Subject Primacy or the Absolutive Hypothesis? Language, 63(4), 856-870. https://doi.org/10.2307/415720 
Hanafi, N., Udin, U., Djuhaeni, E., \& Syahrial, E. (2020). Relativization Strategies of Sasak Ngeno Ngene Dialect in Lombok. Ethical Lingua: Journal of Language Teaching and Literature, 7(1), 11-21. https://doi.org/10.30605/25409190.162

Jalali, H., \& Shojaei, M. (2012). Persian EFL Students' Developmental versus Fossilized $\begin{array}{llll}\text { Prepositional } \text { Errors. The Reading } & \text { Matrix, }\end{array}$ http://dergi.cumhuriyet.edu.tr/cumuscij/article/view/5000118936

Ling, L. H. (2020). Negative Transfer of Malay Language on Non-Chinese Students Learning Mandarin Lexis and its Implications in Teaching Negative Transfer of Malay Language on Non-Chinese Students Learning Mandarin Lexis and its Implications in Teaching. September, 0-9.

Liusti, S. A. (2016). Analisis Kalimat Berdasarkan Pola Kalimat Dasar Dan Kalkulus Predikat. $\begin{array}{lllll}\text { Adabiyyāt: Jurnal Bahasa Dan } & 157 .\end{array}$ https://doi.org/10.14421/ajbs.2016.15203

Ma, C., \& Tan, L. (2013). The Negative Transfer of Sichuan Dialect to the Study of English Pronunciation--Error Analysis on the Supra-segmental Phonemes. Open Journal of Social Sciences, 01(01), 1-4. https://doi.org/10.4236/jss.2013.11001

Phoocharoensil, S., \& Simargool, N. (2010). English Relativization and Learners' Problems. Journal of Pan-Pacific Association of Applied Linguistics, 14(1), 109-129. https://files.eric.ed.gov/fulltext/EJ920506.pdf

Sabbah, S. S. (2015). Negative Transfer: Arabic Language Interference to Learning English (English Language Center Community College of Qatar). Negative Transfer: Arabic Language Interference to Learning English, 4, 269-288.

Said, M. (2012). Negative Transfer of Indonesian Collocations into English and Implications for Teaching English As a Foreign Language. LiNGUA: Jurnal Ilmu Bahasa Dan Sastra, 6(2), 2009-2012. https://doi.org/10.18860/ling.v6i2.1458

Sari, A. M., Andayani, A., \& Sumarlam, S. (2017). Gramatical Functions in Indonesian Relative Clauses in Foreign Students' Writing. Humanus, 16(2), 163. https://doi.org/10.24036/humanus.v16i2.7855

Shibatani, M. (2008). Relativization in Sasak and Sumbawa, eastern Indonesia. Language and Linguistics, 9(4), 865-916. http://citeseerx.ist.psu.edu/viewdoc/download?doi=10.1.1.595.8755\&rep=rep1\&type=p df

Silalahi, R. M. (2016). English Teachers' Perspectives on the Impacts of English as a Global Language Influencing the Indonesian Educational Sysem. ICTTE FKIP UNS 2015, 1, 788-794. https://media.neliti.com/media/publications/170673-EN-english-teachersperspectives-on-the-imp.pdf

Sudarsono, S. (2018). Ungrammatical Constructions: Study on Texts Written by Test Takers to Postgraduate of English Language Education, Tanjungpura University. In Rofiza Aboo Bakar; Suzana AB. Rahim; Farina Nozakiah Tazijan (Ed.), Creativity in Teaching and Learning: a blueprint for success (pp. 29-34). Academy of Language Studies Publication Unit.

https://www.researchgate.net/publication/338570313_CREATIVITY_IN_TEACHING_ AND_LEARNING_A_BLUEPRINT_FOR_SUCCESS

Sudarsono, S. (2011). Voice Changing: Translating Strategy to Generate the Naturalness in Indonesian Texts. In A. Jamil, N. I. Ramli, \& N. A. Aziz (Eds.), Globalisation through Translation: A catalyst for Knowledge and Technological Excellence (pp. 135-145). Malaysian Translators

Association. http://lib.perdana.org.my/PLF/PREVIEW/A18/1008687_PRE.pdf 
Tajareh, M. J. (2015). An Overview of Contrastive Analysis Hypothesis. Cumhuriyet Science Journal, 36(3), 1106-1113. http://dergi.cumhuriyet.edu.tr/cumuscij/article/view/5000118936

Uzun, K. (2020). İNGİLIZCE ÖğrenenTürklerin YazilMetinlerinde Kullandiklari SözcükEşdizimliliklerde OlumsuzDil Aktariminiİncelenmesi. Abant İzzet Baysal Üniversitesi Eğitim Fakültesi Dergisi, $20 \quad$ (2)(June), 1024-1037. https://doi.org/10.17240/aibuefd.2020..-608006

Watcharapunyawong, S., \& Usaha, S. (2013). Thai EFL students' writing errors in different text types: The interference of the first language. English Language Teaching, 6(1), 6778. https://doi.org/10.5539/elt.v6n1p67

Xu, Y. (2011). The Accessibility Hierarchy in Chinese Relative Clauses. In J. B. M. Hung (Ed.), Proceedings of The 16th Conference of Pan-Pacific Association of Applied Linguistics (pp. 68-73). The Chinese University of Hong Kong. http://www.paaljapan.org/conference2011/ProcNewest2011/pdf/oral/1F-2.pdf

Zhao, Y. (2019). Negative Transfer of Mother Tongue in English. Creative Education, 10(05), 940-946. https://doi.org/10.4236/ce.2019.105070 